\title{
Diabesity: an epidemic with its causes, prevention and control with special focus on dietary regime
}

\author{
Nikhil Kumar ${ }^{a}$, Neena Puri ${ }^{b}$, Francesco Marotta ${ }^{c}$, Tejpal Dhewa ${ }^{d}$, Serena Calabro ${ }^{\mathrm{e}}$, \\ Monica Puniya ${ }^{\text {f }}$ Jeon Carter $^{\mathrm{g}}$
}

${ }^{a}$ Department of Life Sciences, Shri Venkateshwara University, JP Nagar, Uttar Pardesh, India; ${ }^{b}$ Department of Industrial Microbiology, Guru Nanak Khalsa College, Haryana, India; ${ }^{c}$ Re-Genera Research group for Aging Intervention and San Babila Clinic, Gender Healthy Aging Unit, Milano, Italy; ${ }^{d}$ Department of Nutrition Biology,Central University of Haryana, Mahendergarh 123029, Haryana, India; ${ }^{\mathrm{e}}$ Department of Veterinary Medicine and Animal Production (DMVPA) University of Napoli, Napoli, Italy; ICAR-National Dairy Research Institute, Karnal, Haryana, India; ${ }^{\mathrm{g}}$ Dept. Health and Kinesiology, Georgia Southern University, USA

Corresponding authors: Francesco Marotta, $\mathrm{PhD}$, Professor, Re-Genera Research group for Aging Intervention and San Babila Clinic, Corso Matteotti 1/A 20121, Milano, Italy and Nikhil Kumar, PhD, Department of Life Sciences, Shri Venkateshwara University, JP Nagar, Uttar Pardesh, India

Submission Date: August 1, 2016; Acceptance date: January 26, 2017; Publication date: January 31,2017

Citation: Kumar N., Puri N., Marotta F, Dhewa T., Calabro S., Puniya M, Carter J.. Diabesity: an epidemic with its causes, prevention and control with special focus on dietary regime. Functional Foods in Health and Disease 2017; 7(1):1-16

\begin{abstract}
Diabesity refers to the complicated conditions of diabetes and obesity occurring simultaneously within a single individual. The incidences of diabetes and obesity are growing at a rapid pace throughout the world that are mainly associated with lifestyle and dietary habits, aside from genetic vulnerability. Authors have reviewed the epidemiology and other negative aspects of diabesity followed by some of the management practices recommended. The declining of traditional lifestyles and dietary patterns is leading to a rapid increase in the prevalence of diabesity that is upcoming as a serious cause of concern world over. Diabetes, obesity, and their associated complications are without doubt a principal issue and threat in developing and under-developed nations. Diabesity has emerged as a major threat. This condition has been described as a slow poison, whose influence cannot be controlled or cured. The dietary measures offer the most viable and effective solution to diabetes onset, in addition to the obese state. The designing of a smart diet (i.e. healthy diet) and selecting gut microbiota having probiotic influence on the host can target in the weight reduction/ management, in addition to stabilizing sugar levels in the blood of an
\end{abstract}


individual. Additionally, the regular physical workout can help an individual in controlling body weight and regulate other biochemical conditions which lead to various types of metabolic disorders. All of these issues are discussed in this review article which covers the causes, prevention, and control of diabesity.

Keywords: Diabetes; obesity; diabesity; gut microbiota; probiotics

\section{Preamble}

The condition of 'diabesity' is a compartively newer terminology associated with the interrelationship between diabetes and obesity firstly coined by Sims et al. 1973 [1, 2]. The condition is also stated to be a link between obesity and diabetes, being characterized as a serious public health issue gradually leading to be an epidemic $[3,4]$. In this review article, we will discuss the epidemiology and negative aspects of diabesity followed by some of the management practices. The incidences of diabetes and obesity are growing at a rapid pace that are mainly associated with lifestyle and dietary habits [5], aside from genetic vulnerability of individuals [6]. A number of research reports indicated an interrelationship between obesity and increased incidences of diabetes and/or diabesity [7, 8]. Accumulation of fat near belly intensifies resistance to insulin and puts on the risk of diabetes development [9]. The occurrence of diabetes is projected to 366 million by 2030 [10]. The nations with the maximum diabetic cases include India, China, USA, Indonesia, and Japan [11]. If the existing trends continue, nearly one fifth of total diabetic cases globally will belong to India by 2030. Overall, diabetes displays an impairment of the body's ability in metabolizing blood glucose of an individual. However, there are multiple types of diabetes that are concerning on a global scale. The main focus should be concentrated primarily on Type- 2 diabetes or T-2D, as over $90 \%$ of diabetics suffer from T-2D. T-2D is largely related to the elevated risk with serious micro and macro-vascular complications [12]. Likewise, the same ratio of frequency and incidence of diabetes connected to micro and macro-vascular complications are reported from Europe. Upsetting people of all age groups, diabetes requires lifestyle changes to be followed seriously. Patients with diabesity have seven fold increases in mortality when compared to healthy individuals. Obesity, which is essentially a physical irregularity, contributes as a high threat issue and mainly for the individuals on the verge developing diabetes independent of their age, race, and physical activities. Nonetheless, epidemiologists have normally ignored such interconnecting factors. Therefore, a link interrelating obesity and diabetes is likely to be quite pivotal. As such, it can be stated that preventing obesity can prove as a vital factor in monitoring diabetes thereby, diabesity. The weight, body mass index (BMI), and waist border are identified as independent risk factors for developing T-2D [13]. In 90\% of patient's weight gain, there has been associations of incidences of T-2D followed by diabesity and co-morbidity concerns. Studies have to present the reason behind weight reduction in controlling, and reversing T-2D and prediabetes. In 1973, Sims and colleagues, revealed the relationship between genetics and environment, detecting the mutual causes of impaired glycemic control and weight gain. Additionally, they also detected the reasons behind the mystery of weight gain in different individuals [1]. Keeping in views, authors reviewed the epidemiology and problems arise due to diabesity followed by some of the control measures. 


\section{Complications and types of Diabetes}

The decline of traditional lifestyles and dietary patterns is giving rise to a rapid increase in the prevalence of diabetes, which is a serious and pressing concern for individuals around the world. Diabetes is the largest health crises of the $21^{\text {st }}$ century, which was resulted in numerous medical complications. In addition to the 415 million people with diabetes, around 318 million adults have impaired glucose tolerance, which has made them prone to developing this disease [14]. Moreover, this figure may rise up to 642 million by the year 2040, as predicted by the reports of United Nations of 2015 [15].

As per the data made available by Diabetes Atlas, $7^{\text {th }}$ edition [16]:

- One out of eleven adults is diabetic, a figure comprising of nearly 415 million people in the world

- Approximately $46.5 \%$ of adults currently have undiagnosed diabetes

- As per the estimate around $12 \%$ of global health expenditure is spent on diabetes

- There are projections that by 2040 , one out of 10 adults will have diabetes

- In pregnant women, one in 7 childbirths is a target of gestational diabetes

- Developing or underdeveloped nations constitute nearly 3 quarters of society with diabetes

- More than half a million children have T-1D

- Every 6 seconds, one person dies of diabetes around the world

"Diabetes" is a metabolic disorder, where the body either produces little insulin or becomes progressively resistant to its action, consequently resulting in a high blood sugar [17]. It is commonly a stage called as postprandial hyperglycemia (PPHG), where blood sugar just after having meals crosses its limit, while the fasting blood glucose remains normal. The persistence of PPHG for a long term progresses into diabetes. The main enzymes involved in monitoring blood glucose (i.e. a -glucosidase and $\alpha$-amylase) plays an important role in diabetes inception and there is an immediate need for further screening the compounds having inhibitory activities against these enzymes that can prove to be helpful in managing PPHG [18, 19]. Probiotic (live microbial supplements) have been recommended to show a significant part in the managing diabetes and other metabolic disorders [20]. The risk of diabetes rises even more with abdominal (visceral) obesity [21,22].

Diabetes can be mainly characterized into the following types:

T-1D: outcomes from the autoimmune devastation of pancreatic $\beta$-cells in genetically apt people [23]. The risk factors include family history, genetics, different infections, and environmental factors, etc. Although, it appears incurable and without insulin, a person may expire having T-1D.

T-2D: the most enlightened form of diabetes, is triggered by resistance to insulin and or impaired insulin production by pancreas, which either of these two mechanisms may predominate. The risk factors include excess body weight, lack of physical inactivity, poor nutritional habits, genetics, family history including gestational diabetes, and stage of development. It can go unnoticed and or undiagnosed for years, but can be easily managed with dietary changes and or by increasing physical activity followed by medication sometimes [24].

Gestational diabetes: in the beginning, it is diagnosed during pregnancy with increase in 
body weight in obstetric women. It is associated with short and long term morbidity for both mother and child. The significance of the immune system to female infertility has been underestimated, although it should be well recognized [25]. Gestational diabetes occurs in 3-10\% of pregnancies and about $90 \%$ of cases of diabetes in pregnancy can lead to risk of developing diabetes both in mother and child [26, 27]. The characteristics of different types of diabetes with reference to various categories is summarized in Table $1[28,29]$.

Table 1. Comparison of various characteristics in different types of diabetes mellitus

\begin{tabular}{|l|l|l|l|}
\hline Characteristics & T-1D & T-2D & Gestational diabetes \\
\hline $\begin{array}{l}\text { Age with highest } \\
\text { prevalence }\end{array}$ & $\begin{array}{l}\text { During childhood and } \\
\text { adolescence }\end{array}$ & During adolescence & During Pregnancy \\
\hline Autoimmunity & Common & Uncommon & Uncommon \\
\hline Family history & Scarce & Recurrent & Recurrent \\
\hline $\begin{array}{l}\text { Insulin } \\
\text { dependence }\end{array}$ & Lifetime & Periodic & Periodic \\
\hline Obesity & Uncommon & Common & Common \\
\hline $\begin{array}{l}\text { Male/female } \\
\text { category }\end{array}$ & $\begin{array}{l}\text { Cases in the female and } \\
\text { male are almost same }\end{array}$ & $\begin{array}{l}\text { Cases of female are } \\
\text { greater than male }\end{array}$ & Mostly pregnant female \\
\hline
\end{tabular}

\section{Causes and Occurrence of Obesity}

Obesity is a serious public health issue which is considered to be started during infancy, when environmental influences employ continuing effects on the risk of its advance during adulthood. Therefore, identifying the variable factors may help in reducing this risk of obesity. Research have shown the role of gut microbiota in controlling body form, energy development, and infections. Thus, these can be vital in pathophysiology of obesity [30]. The excessive accumulation of body fat referred to as obese results from a long-lasting imbalance between food intake and energy outlay. It is a complex condition affecting nearly all persons of diverse ages and socioeconomic groups with serious psychological problems. Unfortunately, this excess accumulation of the fat is seen commonly in modern societies because of changing life styles [31,32,33]. Levels of obesity are shown to increase the possibility of hypertension, T-2D, inflammation, high blood cholesterol, tumor and hormonal inequities in women, resulting in chronic renal disease or failure, dementia, Alzheimer's syndrome, and more. [34]. Many people consider the undue consumption of refined starches or carbohydrates outcomes in the development of obesity, T-2D, and insulin resistance. Overall, a group of disorders called as the twin epidemics diabesity [35, 36, 37, 38, 39]. Studies during the past decade have also linked gut microbiota with metabolic disorders, especially diabetes and obesity in humans. The gut microbiota affects the metabolism of the body by influencing the energy equilibrium and which results in increased body weight. Many Lactobacilli spp. (gut microbes) used as probiotics are found to play active role in body metabolism, but not 
all show desired characters. Thus, there is need to conduct thorough studies focusing on functional properties of beneficial microbes [40, 41]. Probiotics, the live microbial food supplements [42], have beneficiary role in building sound gut microbiota, thereby displaying impact in food intake and hunger of the host, physique and metabolic functions by interpreting gastrointestinal pathways and or modulation of the gut microbial assembly [43, 44, 45].

\section{Diabesity: Cumulative Effect Of Diabetes and Obesity}

Diabesity, as discussed above, is the state of metabolic discrepancy ranging from slight blood sugar to the complete diabetes with potential impact of obesity and a simple pictorial is shown in Fig. 1. Metabolic syndrome comprises, higher triglycerides, fasting blood glucose, blood pressure or belly size, and or lower HDL (i.e. high-density lipoprotein) cholesterol. Uric acid present in blood is also linked with metabolic disorders that can augment the scenario of cardiovascular diseases (CVD), T-2D and diabesity [46]. Those with metabolic syndrome (i.e. diabesity without diabetes) are 4-fold likely to die of CVD.

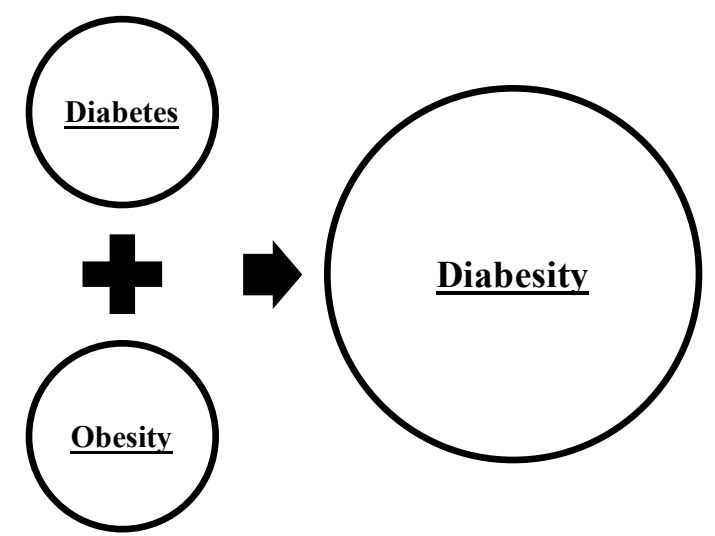

Figure 1. Shows the simple interconnection of Diabesity with obesity and diabetes.

\section{Monitoring of Diabesity}

There is no doubt that diabetes, obesity, and their associated complications are the significant causes of mortality in most of the nations. Diabesity has emerged as a major threat citing like a slow poison, parallel with affluence that can be controlled and not cured [47]. As a supporter for obesity, hypertension, and CVD, diabetes ranks sixth most common cause of mortality. Five million people ranging from 20 to 79 years of age died from diabetes in 2015, which is quite alarming. Diabetes accounted for nearly $14.5 \%$ of overall mortality among people. This is surely higher than the combined deaths from the contagious diseases (i.e. tuberculosis, HIV/AIDS and malaria). Close to half (i.e. $47 \%$ ) of deaths due to diabetes are in people below 60 years as reported [48]. However, despite so much research, the problem of diabetes still remains fully unsolved. Investigations highlight the regulation of blood glucose metabolism for diabetics, as the occurrence of hypoglycemia over a long period of time is one of the first abnormalities associated with acute diabetes. Hyperglycemia is expressed in the form of fasting and PPHG. Researchers have indicated the importance of PPHG over fasting hyperglycemia, as it may start a decade before the onset of diabetes and are also designated as major risk factors [49]. The treatment of diabetes is quite 
complicated, as it is a multifactorial disease having chronic PPHG and disturbances in carbohydrate, lipid, and protein metabolism. Different medicines target one or more of these risk factors, but a few focus on the management and regulation of these factors. As diabetes is primarily a disorder of carbohydrate metabolism, the enzymes involved in it could thereby be selectively targeted, as to develop the potential anti-hyperglycemic drugs. The inhibition of dietary carbohydrate absorption through inhibition of pancreatic, salivary amylases, and intestinal $\alpha$ glucosidase has emerged as one of the most promising approaches for controlling PPHG in prediabetics. Presently, in market acarbose, miglitol, and voglibose are the well-known $\alpha$-glucosidase inhibitors, but their regular use has been associated with certain serious side-effects such as hepatic disorders, kidney dysfunction, and other negative gastrointestinal symptoms (i.e. bloating, diarrhea and flatulence) [50,51]. Additionally, a rise in the frequency of renal tumors and severe hepatic damage by acarbose [52] have also been reported.

Generally, it is important to diagnose T-2D at an initial phase. A person's fasting blood glucose more than $87 \mathrm{mg} / \mathrm{dl}$ indicates the risk of developing diabetes while the group having 81 $\mathrm{mg} / \mathrm{dl}$ are at lowest-risk of its onset. Commonly, medical practitioners remain unaffected till the blood glucose rises above $110 \mathrm{mg} / \mathrm{dl}$, or worse when the $126 \mathrm{mg} / \mathrm{dl}$ the range in principle confirms diabetes. Identifying the problem at this point seems a bit late. Additionally, the pancreatic damage can be avoided if doctors would diagnose pre-diabetes decades before its occurrence. Abnormal insulin and blood sugar should be treated at the earliest possibility to achieve optimal results [53]. The risk of myocardial infarction in people with diabetes is almost equal to the non-diabetics. Diabetes is also a threat for unexpected death as of a stroke (1.5 to 4.0 times), where the zones of brain expire as of bleeding and arterial blockage. Diabetics are suffering from different metabolic syndromes, i.e. high adiposity, PPHG, dyslipidemia, and hypertension. Diabetes leads to renal failure in almost $44 \%$ of T-2D patients and is also one of the single most common causes of renal inefficiency in diabetics, as this complication remains undiagnosed until advanced. Before the patients are diagnosed with diabetes, nearly $7 \%$ of patients already have microalbuminuria the first abnormality of the diabetic nephropathy [54]. If this microalbuminuria remains untreated, around $80 \% \mathrm{~T}-1 \mathrm{D}$ and $20-40 \% \mathrm{~T}-2 \mathrm{D}$ patients progress to nephropathy. The end-stage renal failure is quite common in T-1D rather than T-2D, because the latter is more likely to die as a result of CVD. Uncontrolled blood-pressure and glucose can damage the nerves in human body leading to the complications of feebleness, urination, and digestion, mainly affecting the areas of limbs. The nerve injury in these regions (i.e. peripheral neuropathy) results in the loss of sensation in limbs of an individual, causing burning, and acute pain with extreme sensitivity to touch, with aching in the affected parts occurring simultaneously [55]. The risks for peripheral neuropathy shows deprived glycemic switch, reliant on the age of the patient, period of diabetes occurrence, tobacco consumption, hypertension, and dyslipidemia [56]. The additional sovereign hazard issues for peripheral neuropathy are lengthier height, $\mathrm{CVD}$, severe ketoacidosis, microalbuminuria etc. Unlike diabetic retinopathy, pathogenesis of peripheral neuropathy is linked with metabolic mechanisms (i.e. vascular and non-vascular), but the exact mechanism is still not clear [57]. In normal individuals, glucose levels are maintained within a narrow range (i.e. less than $110 \mathrm{mg} / \mathrm{dl}$ ) with continuous secretion of insulin in low amounts that regulate the hepatic glucose metabolism. Multiple factors are responsible for PPHG concentrations, such as rate of carbohydrate absorption, glucose metabolism, insulin, and glucagon secretion, in addition to the control, amount, and 
structure of the mealtime [58]. Moreover, the occurrence of type 1 diabetes (T-1D) and T-2D in teens is growing at a rapid pace worldwide with signals of geographical variances in development, increasing $3 \%$ annually $[59,60]$. However, reliable data on diabesity is scanty. Moreover, day by day new information is constantly coming in. As with the significant rise in T-1D and T-2D diabetes in early adulthood, there will be a burden on society [61]. India is home to the second largest number of children with T-1D after the USA, and accounts for the majority of children with T-1D in Asiatic region. Thereby, an increasing amount of information with monitoring the aspect of the diabetes epidemic is the need of hour in order to combat the dreaded disease.

\section{Strategies For Prevention and Control}

With increasing availability of newer pharmacologic options, the management of diabetes in present era has shifted its attention to a greater extent in society. The general preventive and control measures include the regular inspection, physical workout, and healthy diet which will certainly be beneficial. The different diabesity management strategies proposed include the following interventions:

\section{Dietary Regulations and Physical Exercise}

The diet plays a very significant role in controlling the human health, in addition to diabetes. The dietary management is much more than the simple reduction of energy expenditure. Among these are cutting carbohydrate intake or other strategies for reducing their degradation in the gastrointestinal tract, which are the key determinants in its prevention or control. The diet comprises large amount of unprocessed, fresh and healthy fruits and vegetables. A fair quantity of sinewy proteins and advantageous fats, in addition to consuming ostensibly treated carbohydrates and saturated or Tran's fats can considerably decrease PPHG [62]. The consumption of foods with low glycemic index also plays an important role in controlling diabesity [63]. The main reasons for occurrence of insulin resistance is associated with physical inactivity and or a sedentary lifestyle of the sufferer, which in turn increases PPHG. Therefore, during dietary management physical workouts prove to be beneficial in attaining desired weight with better insulin sympathy [64].

\section{Pharmacological Linked Approaches}

While most of the antihyperglycemic agents have favorable effects when occupied orally, the state of progress still varies with the class of drug used for the treatment of diabetes. Sulphonylureas, exert their antidiabetic effects by increasing insulin secretion from pancreatic $\beta$-cells [65]. For example, while metformin regulates hepatic gluconeogenesis, due to some side effects on plasma blood glucose it also has little effect on improving the diabesity [66]. While several drugs are available in the market, an effective and widely acceptable solution to the menace of diabesity is still awaited. It is possible with ongoing researches on gut microbiota that in future there are some biological answers to this chronic disease.

\section{Food and Microbial (Probiotic) Based Interventions}

The use of herbs and other medicinal plants have always functioned as a key source of drugs in prevention and treatment of chronic diseases like diabetes, obesity, or diabesity, and are also considered to be the most cost effective natural source of health care [67]. As of now, a number of 
plants have been screened for their hypoglycemic characteristics comprising commonly available edible flora (i.e. wax gourd, lotus root, bitter melon, pumpkin, wheat, celery etc.). Furthermore, the practice of herbal medication is being cheered as of the concern raised over wellbeing of pure chemical medicines [68]. The cure using natural source remedies looks to bid healthier conducts of handling these diseases because their high efficiency, lower or no side effects, and price tag. Due to the fast-growing nature of microbes, the synthesis of these inhibitors by the microorganism offers an economical large scale production in industry in order to meet the demand. The alimental $\alpha$-glucosidase and $\alpha$-amylase inhibitors acting in gut moderately deter the enzymatic breakdown of soluble starches, which have been recognized as a natural and safe method in controlling PPHG [69]. Therefore, plants or herbs have not only been thoroughly screened for diabesity control, but also a number of edible products including microbes or microbial based products (i.e. probiotics) have also been reported. Only few studies regarding the enzyme inhibitory activity of fermented food products (i.e. douche, koumiss, kefir, viili etc.) are available [70]. Work in this direction regarding this topic is in progress at different research organizations. For example, a Chinese fermented soybean product (viz. douchi) has been successfully examined for $\alpha$-glucosidase inhibitory activity in vitro and in vivo [71, 71,73, 74]. The strain of microorganisms used in fermentation of douchi have been reported to show enzyme inhibition action. In 2007, Chen and colleagues reported that fermentation of soybean with Aspergillus oryzae possess greater $\alpha$ glucosidase inhibition compared to the one with Aspergillus elegans and Rhizopus arrhizus. Similarly, the fermentation of douchi with Bacillus subtilis improves its $\alpha$-glucosidase inhibitory activity [75]. Okara or Soy pulp is a yellowish fluid consisting of insoluble parts of soybean, obtained during the production of soy milk and its fermentation with different microorganism increased the nutritional value, as well as $\alpha$-glucosidase inhibitory activity proving to be a good source for diabetics [76]. Similarly, genistein (a phytoestrogen) obtained after fermentation of soybean shows inhibition of $\alpha$-glucosidase [77] of mold origin. The fermented soy milk added with bokbunja (Korean fruit wine) showed higher inhibitory activities than fermented soy milk extracts against $\alpha$-glucosidase and PPHG in animal models [78]. In 2007, Apostolidis and his colleagues [79] evaluated the inhibitory activity against $\alpha$-glucosidase and $\alpha$-amylases by herbal plants and fungal enriched cheese, resulting in varied degree of action. Azadirachta indica yogurt water, extract was inhibitorier for $\alpha$-glucosidase and $\alpha$-amylase than plain yogurt. Similarly, Allium sativum displayed better $\alpha$-amylase and $\alpha$-glucosidase inhibition in camel milk yogurt in contrast to yogurt from cow milk [80]. The fresh edible green plant leafs and the fresh eggplant, bitter gourd, the small bronchial water extract all show high inhibitory activity for $\alpha$-amylase, related to $\alpha$-glucosidase [81]. Various traditional African vegetables shows significant inhibition against $\alpha$ amylase (i.e. $>70 \%$ ) [82]. Japanese and Chinese vegetables were also screened in an enzyme immobilized system for their $\alpha$-glucosidase inhibitory activities and except for tomato all other raw vegetables (i.e. radish, cabbage, onion, cucumber, and carrot) exhibited an inhibitory effect on $\alpha$-glucosidase than boiled samples [83]. Likewise, brinjal, onion, mushroom Ganoderma lucidum, garlic, and sea cucumber have also been tested (in vitro and in vivo) for their $\alpha$ glucosidase and $\alpha$-amylase inhibition role [84, 85, 86, 87, 88, 89]. The cereal grains constitute the most important part of human diet playing an important role in diabetes management via inhibition of related digestive enzymes. These include millets (i.e. finger, sorghum, foxtail etc.) [90], Bengal gram [91], wheat [92], beans $[93,94]$. and several others. The spices are the common dietary 
additives that contribute to the taste and flavor of foodstuffs. Additionally, spices also exert several beneficial physiological effects, including the antidiabetic influence. Commonly used spices in Indian cuisine such as fenugreek, fennel powder, cardamom powder, mustard, ginger, cinnamon, and turmeric have been explored for anti-diabetic activity [95]. Fenugreek galactomannan lowers the level of maltase, lactase, and sucrase activities in diabetic experimental rats [96]. The $\alpha$ amylase inhibitory activities of different common Cameroonian spices concluded that the aqueous extracts had more than $75 \%$ inhibitory activity [97]. Therefore, these spices can be explored for their role in the management of some chronic diseases. Additionally, the fruits consist different bioactive compounds and antioxidants, improving resistance of the body involving traditional remedies treating the disorders of diabetes, obesity and or diabesity. Research indicated that fruits such as apples [98, 99], watermelon [83], berries [100], grapes [101, 102], sugarcane [103], mulberry [104], jamun [105, 106], pineapple [107], mango [108], maple [109, 110], indian gooseberry [111], chinese yam [112], kiwifruit [113], and more possess strong inhibitory activity against $\alpha$-glucosidase and $\alpha$-amylase under in vitro as well as in vivo, thereby exhibiting the role in prevention of diabesity and verifying it to be an operative and most acceptable answer to the menace of diabesity. Therefore, we can say that a little consideration to their part can bring healthy outcomes in our world.

\section{CONCLUSIONS AND FUTURE PROSPECTS}

The most accepted way of controlling the epidemic of diabetes, obesity and or diabesity is to screen the human beings routinely for an early start, before its further advancement, which can thereby result in a healthy life. There is a requirement for timely detection of symptoms and it is evident that diabesity is an epidemic with major wellbeing and financial burden on the society. However, authentic data is obligatory for estimating the financial load, primarily in developing countries because of diabesity. Further research is essentially required for exploring the exact chemical nature, mechanism of action and structure elucidation of different natural and microbial constituents with agreed GRAS status that may help in the development of functional, safe, and economic antidiabetic foods and can target diabesity via inhibiting the digestive enzymes in-situ. Furthermore, international collaborations and synergies among researchers, long-term human trials, controlled clinical examinations and strong willingness to increase sharing of research database, awareness among people are the only way forward to counter the dreaded diabesity.

Competing Interests: The authors have no financial interests or any other conflicts of interest to disclose.

Authors' Contributions: All authors contributed to this review.

\section{REFERENCES}

1. Sims EAH, Danforth E, Horton ES, Bray GA, Glennon JA, Salans LB: Endocrine and metabolic effects of experimental obesity in man. Recent Prog Horm Res 1973, 29:457496.

2. Kaufman FR: Diabesity: a doctor and her patients on the front lines of the obesity-diabetes epidemic. N Y: Bantam Books 2006. 
3. Dang MN, Hashem BES: The epidemiology of obesity. Gastroenterol Clin North Am 2010, 39:1-7.

4. Farag Y, Gaballa M: Diabesity: An overview of a rising epidemic. Nephrology Dialysis Transplan 2011, 26:28-35.

5. Zimmet P, Alberti KG, Shaw J: Global and societal implications of the diabetes epidemic. Nat 2001, 414:782-787.

6. Sladek R, Rocheleau G, Rung J, Dina C, Shen L, Serre D, Boutin P, Vincent D, Belisle A, other authors: A genome-wide association study identifies novel risk loci for type 2 diabetes. Nat 2007, 445:881-885.

7. Wannamethee SG, Shaper AG, Walker M: Overweight and obesity and weight change in middle aged men: impact on cardiovascular disease and diabetes. J Epid Commu Health 2005, 59:134-139.

8. Hart CL, Hole DJ, Lawlor DA, vey-Smith G: How many cases of type 2 diabetes mellitus are due to being overweight in middle age? Evidence from the Midspan prospective cohort studies using mention of diabetes mellitus on hospital discharge or death records. Diabet Med 2007, 24:73-80.

9. Montague CT, O'Rahilly S: The perils of portliness: causes and consequences of visceral adiposity. Diab 2000, 49:883-888.

10. Wild S, Roglic G, Green A, Sicree R, King H: Global prevalence of diabetes: estimates for the year 2000 and projections for 2030. Diab Care 2004, 27:1047-1053.

11. Xu L, Xie X, Wang S, Wang Y, Jonas JB: Prevalence of diabetes mellitus in China. Exp Clin Endo Diab 2008, 116:69-70.

12. Mohan V, Mathur P, Deepa R, Deepa M, Shukla DK, Menon GR, Anand K, Desai NG, Joshi PP, other authors: Urban rural differences in prevalence of self-reported diabetes in India - the WHO-ICMR Indian NCD risk factor surveillance. Diab Res Clin Pract 2008, 80:159-168.

13. Narayan KM, Boyle JP, Thompson TJ, Gregg EW, Williamson DF: Effect of BMI on lifetime risk for diabetes in the U.S. Diabetes Care 2007, 30:1562-1566.

14. Piero MN, Nzaro GM, Njagi JM: Diabetes mellitus - a devastating metabolic disorder. Asian Journal of Biomed and Pharma Sci 2014, 04:1-7.

15. United Nations: World Population Prospects. Geneva, Switzerland 2015.

16. Diabetes Atlas 7th edition. www.diabetesatlas.org 2015.

17. Alberti KGMM, DeFronzo RA, Zimmet P: International textbook of diabetes mellitus, 2nd edn. Chichester, NY: J. Wiley 1997.

18. Ramchandran L, Shah NP: Proteolytic profiles and angiotensin-I converting enzyme and $\alpha$ glucosidase inhibitory activities of selected lactic acid bacteria. Journal of Food Sci 2008, 73: M75-M81.

19. Ramchandran L, Shah NP: Effect of exopolysaccharides and inulin on the proteolytic, angiotensin-I-converting enzyme-and $\alpha$-glucosidase-inhibitory activities as well as on textural and rheological properties of low-fat yogurt during refrigerated storage. Dairy Sci Tech 2009, 89:583-600.

20. Razmpoosh E, Javadi M, Ejtahed HS, Mirmiran P: Probiotics as beneficial agents in the management of diabetes mellitus: a systematic review. Diabe Metab Res Rev. 2016, 32, 
143-168.

21. Mittelman SD, Van-Citters GW, Kirkman EL, Bergman RN: Extreme insulin resistance of the central adipose depotin vivo. Diab 2002, 51:755-761.

22. Arsenault BJ, Cartier A, Cote M, Lemieux I, Tremblay A, Bouchard C, Perusse L, Despres JP: Body composition, cardio-respiratory fitness, and low-grade inflammation in middleaged men and women. Am Journal Cardiol 2009, 10:240-246.

23. Bluestone JA, Herold K, Eisenbarth G: Genetics, pathogenesis and clinical interventions in type 1 diabetes. Nat 2010, 464:1293-1300.

24. McNaughton D: Diabesity' down under: overweight and obesity as cultural signifiers for type 2 diabetes mellitus. Crit Pub Hlth 2013, 23:274-288.

25. Nitert MD, Barrett HL, Foxcroft K, Tremellen A, Wilkinson S, Lingwood B, Tobin JM, McSweeney C, O'Rourke P, McIntyre HD, Callaway LK: SPRING: an RCT study of probiotics in the prevention of gestational diabetes mellitus in overweight and obese women. BMC Preg and Chil 2013:13:50.

26. Berkowitz GS, Lapinski RH, Wein R, Lee D: Race/ethnicity and other risk factors for gestational diabetes. Am Journal of Epid 1992, 135:965-973.

27. Feig DS, Zinman B, Wang X, Hux JE: Risk of development of diabetes mellitus after diagnosis of gestational diabetes. Canad Med Assoc Journal 2008, 179:229-234.

28. Libman I, Arslanian SA: Type II diabetes mellitus: No longer just adults. Pediatr Ann 1999, 28:589-593.

29. Vitacolonna E, Lapolla A, Nenno BD, Passante A, Bucci I, Giuliani C, Cerrone D, Capani F, Monaco F, Napolitano G: Gestational Diabetes and Thyroid Autoimmunity. Int Journal of Endocr 2012.

30. Sanchez M, Panahi S, Tremblay A: Childhood Obesity: A Role for Gut Microbiota? Int Journal of Env Res and Pub Hlth 2014, 12:162-175.

31. Bray, GA: The epidemic of obesity and changes in food intake: the Fluoride Hypothesis. Physiol Behav 2004, 82:115-121.

32. Yaturu S, Jain SK: Obesity and type 2 diabetes. In Bagchi D and Preuss HG (eds). Obesity. Epidmiology, Pathophysiology, and Prevention. Boca Raton, FL: CRC Press 2007:139154.

33. Gardner DC, Kiazand A, Alhassan S, Kim S, Stafford RS, Balise RR, Kraemer HC, King AC: Comparison of the Atkins, Zone, Ornish, and learn diets for change in Weight and Related risk factors among overweight premenopausal women the A to $\mathrm{Z}$ weight loss study: A Randomized Trial. JAMA 2007, 297:969-977.

34. Iacobellis G, Ribaudo MC, Leto G, Zappaterreno A, Vecci E, Di-Mario U, Leonetti F: Influence of excess fat on cardiac morphology and function: study in uncomplicated obesity. Obes Res 2002, 10:767-763.

35. Arslanian S: Type 2 diabetes mellitus in children: pathophysiology and risk factors. Horm Res 2002, 57:19-28.

36. Green A, Christian NH, Pramming SK: The changing world demography of type 2 diabetes. Diabetes Metab Res and Rev 2003, 19:3-7.

37. Black E, Holst C, Astrup A, Toubro S, Echwald S, Pedersen O, Sørensen TI: Long-term influences of body-weight changes, independent of the attained weight, on risk of impaired 
glucose tolerance and type 2 diabetes. Diabet Med 2005, 22:1199-1205.

38. Saljoughian M: Diabesity: A Global Epidemic. US Pharm 2007, 32:HS40-HS47.

39. Preuss HG: Bean Amylase Inhibitor and Other Carbohydrate Absorption Blockers: Effects on Diabesity and General Health. Journal of the Am College of Nutr 2009, 28:266-276.

40. Gibson GR, Fuller R: Aspects of in vitro and in vivo research approaches directed towards identifying probiotics for human use. J Nutr 2000, 130:391-395.

41. Puniya M, Sangu KPS, Bhardwaj A, Kumar S, Dhewa T: Isolation and Characterization of Lactobacillus spp. of Human Origin for Studying their Prevalence. Research , Reviews: Journal of Da Sci Tech 2014, 2:7-15.

42. Nagpal R, Shrivastava B, Kumar N, Dhewa T, Sahay H: Microbial feed additives.In Rumen Microbiology: From Evolution to Revolution Springer India 2015:161-175.

43. Puniya M, Sangu KPS, Bharadwaj A, Gupta D, Kumar S, Dhewa T, Pant S: Probiotic and functional attributes of Lactobacillus spp isolated from human faeces. Journal of Res Antimicrobiol 2012, 1: 0342-042.

44. Indias IM, Cardona F, Tinahones FJ, Queipo-Ortuño MI: Impact of the gut microbiota on the development of obesity and type 2 diabetes mellitus. Front in Microb 2014, 5:190.

45. Kobyliak N, Conte C, Cammarota G, Haley AP, Styriak I, Gaspar L, Fusek J, Rodrigo L, Kruzliak, P: Probiotics in prevention and treatment of obesity: a critical view. Nutr Metab 2016, 13-14.

46. Gurusamy N, Vijayaraghavalu S, Alhazzani A, Chandramoorthy H: The enigma of uric acid in metabolic syndrome. Diab 2015, 1:29-30.

47. Unwin N, Gan D, Whiting D: The IDF Diabetes Atlas: providing evidence, raising awareness and promoting action. Diabe res and clinical pract 2010, 87:2-3.

48. World Health Organization :Global Health Observatory Data Repository Geneva, Switzerland 2013.

49. Chang AM, Smith MJ, Bloem CJ, Galecki AT, Halter JB: Effect of lowering postprandial hyperglycemia on insulin secretion in older people with impaired glucose tolerance. Am Journal of Phy-Endocr and Metab 2004, 287:E906-E911.

50. Chiasson JL, Josse RG, Gomis R, Hanefeld M, Karasik A, Laakso M: Acarbose for prevention of type 2 diabetes mellitus: the STOP-NIDDM randomised trial. The Lanc 2002, 359:2072-2077.

51. Inzucchi SE: Oral antihyperglycemic therapy for type 2 diabetes. JAMA: The Journal of the Ame Med Asso 2002, 287:360-372.

52. Cheng AYY, Fantus IG: Oral antihyperglycemic therapy for type 2 diabetes mellitus. Ca Med Asso Journal 2005, 172:213-226.

53. Henry B, Kalynovskyi S: Reversing diabetes and obesity naturally: a NEWSTART lifestyle program. Diabetes Educ 2004, 30: 48-50, 55-56, 58-59.

54. Gross JL, Azevedo-de MJ, Silveiro SP, Canani LH, Caramori ML, Zelmanovitz T: Diabetic nephropathy: diagnosis, prevention, and treatment. Diab Care 2005, 28:164-176.

55. Boulton AJ, Vinik AI, Arezzo JC, Bril V, Feldman EL, Freeman R, Malik RA, Maser RE, Sosenko JM , Ziegler D: Diabetic neuropathies. Diab Care 2005, 28:956-962.

56. Tesfaye S, Chaturvedi N, Eaton SEM, Ward JD, Manes C, Ionescu-Tirgoviste C: Vascular risk factors and diabetic neuropathy. New Eng Journal of Med 2005, 352:341-350. 
57. Cameron N, Eaton S, Cotter M, Tesfaye S: Vascular factors and metabolic interactions in the pathogenesis of diabetic neuropathy. Diabetol 2001, 44:1973-1988.

58. Tibaldi J: Importance of postprandial glucose levels as a target for glycemic control in type 2 diabetes. South Med Journal 2009, 102:60-66.

59. Patterson CC, Dahlquist GG, Gyürüs E, Green A, Soltész G: EURODIAB Study Group. Incidence trends for childhood type 1 diabetes in Europe during 1989- 2003 and predicted new cases 2005: a multicentre prospective registration study. Lancet 2009, 373: 2027-2033.

60. Hannon TS, Rao G, Arslanian SA: Childhood obesity and type 2 diabetes mellitus. Pedia 2005, 116:473-480.

61. Fazeli FS, Van-der-Aa MP, Vander VMMJ, Knibbe CAJ, Boer-de A: Global trends in the incidence and prevalence of type 2 diabetes in children and adolescents: a systematic review and evaluation of methodological approaches. Diabeto 2013, 56:1471-88.

62. O'Keefe JH, Bell DSH: Postprandial hyperglycemia/hyperlipidemia (postprandial dysmetabolism) is a cardiovascular risk factor. The Am Journal of Card 2007, 100:899904.

63. Brand-Miller J, Hayne S, Petocz P, Colagiuri S: Low glycemic index diets in the management of diabetes. Diab Care 2003, 26:2261-2267.

64. Horton ES: Role and management of exercise in diabetes mellitus. Diab Care 1988, 11:201211.

65. Rendell, M: The role of sulphonylureas in the management of type 2 diabetes mellitus. Drugs 2016, 64:1339-1358.

66. Ceriello A, Cavarape A, Martinelli L, Da-Ros R, Marra G, Quagliaro L: The post-prandial state in Type 2 diabetes and endothelial dysfunction: effects of insulin aspart. Diab Med 2004, 21: 171-175.

67. Ahad HA, Kumar C, Nanda P, Bhanu TU, Ravindra B, Mohan G: Traditional indian herbs used for diabetes. Journal of Inno Trends in Pharma Sci 2010, 1:69-78.

68. Dubey N, Kumar R, Tripathi P: Global promotion of herbal medicine: India's opportunity. Curr Sci 2004, 86:37-41.

69. Fonseca V: Clinical significance of targeting postprandial and fasting hyperglycemia in managing type 2 diabetes mellitus. Curr Med Res and Opin 2003, 19:635-631.

70. Dhewa T, Mishra V, Kumar N, Sangu K.P.S: Koumiss: The Nutritional and Therapeutic Values. Fermented Foods and Beverages Series. In Fermented Milk and Dairy Products CRC Press 2015:483-494.

71. Fujita H, Yamagami T, Ohshima K: Long term ingestion of a fermented soybean derived touchi extract with $\alpha$-glucosidase inhibitory activity is safe and effective in humans with borderline and mild type-2 diabetes. The Journal of Nutr 2001a, 131:2105-2108.

72. Fujita H, Yamagami T, Ohshima K: Fermented soybean derived water-soluble touchi extract inhibits $\alpha$-glucosidase and is antiglycemic in rats and humans after single oral treatments. The Journal of Nutr 2001b, 131:1211-1213.

73. Fujita H, Yamagami T, Ohshima K: Long term ingestion of Touchi-extract, an [alpha]glucosidase inhibitor, by borderline and mild type-2 diabetic subjects is safe and significantly reduces blood glucose levels. Nutr Research 2003, 23:713-722.

74. Chen J, Cheng YQ, Yamaki K, Li LT: Anti $\alpha$-glucosidase activity of Chinese traditionally 
fermented soybean (douchi). Food Chem 2007, 103:1091-1096.

75. Zhu Y, Li X, Huang Z, Li L, Su Y: Improving Anti- $\alpha$-Glucosidase Activity of Douchi Koji Using a Newly Isolated Strain of Bacillus subtilis B2. Int Journal of Food Eng 2011, 7:2029.

76. Haijie ZYCYL, Kohji LLY. (2008). $\alpha$-Glucosidase Inhibitory Activity of Okara Fermented with Various Microorganisms. Journal of the Chinese C and O Asso 2008:4.

77. Lee DS, Lee SH: Genistein, a soy isoflavone, is a potent $\alpha$-glucosidase inhibitor. FEBS Letters 2001, 501:84-86.

78. Ju HE, Han JS: Hypoglycemic effect of fermented soymilk added with bokbunja (Rubus coreanus Miquel) in diabetic mice. Food Sci and Biotech 2010, 19:1041-1046.

79. Apostolidis E, Kwon YI, Ghaedian R, Shetty K: Fermentation of milk and soymilk by Lactobacillus bulgaricus and Lactobacillus acidophilus enhances Functionality for potential dietary management of hyperglycemia and hypertension. Food Biotechn 2007, 21:217-236.

80. Shori AB, Baba A: Antioxidant activity and inhibition of key enzymes linked to type- 2 diabetes and hypertension by Azadirachta indica yogurt. Journal of Saudi Chem Soc 2011, 17:295-301.

81. McCue P, Lin YT, Labbe RG, Shetty: Sprouting and Solid-State Bioprocessing by Rhizopus oligosporus Increase the In Vitro Antibacterial Activity of Aqueous Soybean Extracts against Helicobacter pylori. Food Bio 2005b, 18:229-249.

82. Odhav B, Kandasamy T, Khumalo N, Baijnath H: Screening of African traditional vegetables for their $\alpha$-amylase inhibitory effect. Journal of Med Plants Res 2010, 4: 15021507.

83. Kawada Y, Miura M, Gomyo T: Inhibitory effect of vegetables, fruits and herbs on $\alpha-$ glucosidase in an immobilized enzyme assay system. Food Sci and Tech Res 2006 12:275277.

84. Wongsa $\mathrm{P}$, Chiawarit J, Zamaluddin A: In vitro screening of phenolic compounds, potential inhibition against $\alpha$-amylase and $\alpha$-glucosidase of culinary herbs in Thailand. Food chem 2011, 131:964-971.

85. Kim SH, Jo SH, Kwon YI, Hwang JK: Effects of onion (Allium cepa L.) extract administration on intestinal $\alpha$-glucosidases activities and spikes in postprandial blood glucose levels in SD rat's model. International Journal of Mol Sci, 2011, 12:3757-3769.

86. Nguyenab H, Kima S: Three compounds with potent $\alpha$-glucosidase inhibitory activity purified from sea cucumber Stichopus japonicas. Summer Program in Sensory Evaluation 2011:112-122.

87. Fatmawati S, Shimizu K, Kondo R: Ganoderol B: A potent $\alpha$-glucosidase inhibitor isolated from the fruiting body of Ganoderma lucidum. Phytomed 2011, 18:1053-1055.

88. Adisakwattana S, Pudhom K, Yibchok-Anun S: Influence of the methanolic extract from Abutilon indicum leaves in normal and streptozotocin-induced diabetic rats. African Journal of Biotech 2010, 8:2011-2015.

89. Nickavar B, Yousefian N: Inhibitory effects of six Allium species on $\alpha$-amylase enzyme activity. Iranian Journal of Pharma Res 2009, 8:53-57.

90. Shobana S, Sreerama Y, Malleshi N: Composition and enzyme inhibitory properties of finger millet (Eleusine coracana L.) seed coat phenolics: Mode of inhibition of $\alpha$ - 
glucosidase and pancreatic amylase. Food Chem 2009, 115:1268-1273.

91. Prathapan A, Fahad K, Thomas BK, Philip RM, Raghu KG: Effect of sprouting on antioxidant and inhibitory potential of two varieties of Bengal gram (Cicer arietinum L.) against key enzymes linked to type-2 diabetes. International Journal of Food Scie and Nutr 2011, 62:234-238.

92. Liu L, Deseo MA, Morris C, Winter KM, Leach DN: Investigation of $\alpha$-glucosidase inhibitory activity of wheat bran and germ. Food Chem 2010, 26:553-561.

93. Barrett ML, Udani JK: A proprietary alpha-amylase inhibitor from white bean (Phaseolus vulgaris): A review of clinical studies on weight loss and glycemic control. Nutr Jrnl 2011, $10-24$.

94. Kwon YI, Apostolidis E, Kim YC, Shetty K: Health benefits of traditional corn, beans, and pumpkin: in vitro studies for hyperglycemia and hypertension management. Journal of Med Food 2007, 10:266-275.

95. McCue P, Kwon YI, Shetty K: Anti-amylase, anti-glucosidase and anti-angiotensin-Iconverting enzyme potential of selected foods. Journal of Food Biochem 2005a, 29:278294.

96. Hamden K, Jaouadi B, Carreau S, Bejar S, Elfeki A: Inhibitory effect of fenugreek galactomannan on digestive enzymes related to diabetes, hyperlipidemia, and liver-kidney dysfunctions. Biotech and Bioproc Engin 2010, 15:407-413.

97. Etoundi C, Kuaté D, Ngondi J, Oben J: Anti-amylase, anti-lipase and antioxidant effects of aqueous extracts of some Cameroonian spices. Journal of Nat Pro 2010, 3:165-171.

98. Barbosa ACL, Pinto MDS, Sarkar D, Ankolekar C, Greene D, Shetty K: Influence of varietal and $\mathrm{pH}$ variation on antihyperglycemia and antihypertension properties of long term stored apples using in vitro assay models. Journal of Food Biochem 2012, 36:479-493.

99. Barbosa ACL, Pinto MDS, Sarkar D, Ankolekar C, Greene D, Shetty K: Varietal influences on antihyperglycemia properties of freshly harvested apples using in vitro assay models. Journal of Med Food 2010, 13:1313-1323.

100. McDougall GJ, Stewart D: The inhibitory effects of berry polyphenols on digestive enzymes. Biofact 2005, 23:189-195.

101. Hogan S, Zhang L, Li J, Sun S, Canning C, Zhou K: Antioxidant rich grape pomace extract suppresses postprandial hyperglycemia in diabetic mice by specifically inhibiting $\alpha$ glucosidase. Nutrition Metab 2010, 7:1-9.

102. Zhang L, Hogan S, Li J, Sun S, Canning C, Zheng SJ: Grape skin extract inhibits mammalian intestinal $\alpha$-glucosidase activity and suppresses postprandial glycemic response in streptozocin treated mice. Food chem 2010, 126:466-471.

103. Holt S, Jong V, Faramus E, Lang T, Brand MJ: A bioflavonoid in sugar cane can reduce the postprandial glycaemic response to a high-GI starchy food. Asia Pacific Journal of Cl Nutr 2003, 12:S66.

104. Hansawasdi, C, Kawabata J: $\alpha$-Glucosidase inhibitory effect of mulberry (Morus alba) leaves on Caco-2. Fitoterap 2006, 77:568-573.

105. Karthic K, Kirthiram K, Sadasivam S, Thayumanavan B: Identification of $\alpha$-amylase inhibitors from Syzygium cumini Linn seeds. Indian Journal of Exp Bio 2008, 46:677-680.

106. Shinde J, Taldone T, Barletta M, Kunaparaju N, Hu B, Kumar S: $\alpha$-Glucosidase inhibitory 
activity of Syzygium cumini (Linn.) Skeels seed kernel in vitro and in Goto-Kakizaki (GK) rats. Carboh Res 2008, 343:1278-1281.

107. Correia RTP, McCue P, Vattem DA, Magalhães M, Macedo GR, Shetty K: Amylase and Helicobacter pylori inhibition by phenolic extracts of pineapple wastes bioprocessed by Rhizopus oligosporus. Journal of Food biochem 2004, 28:419-434.

108. Kumar D, Mitra A, Manjunatha M: Studies on the anti-diabetic and hypolipidemic potentials of mangiferin (Xanthone Glucoside) in streptozotocin induced Type 1 and Type 2 diabetic model rats. International Journal of Adva in Pharmac Sci 2011, 1:75-85.

109. Honma A, Koyama T, Yazawa K: Anti hyperglycemic effects of sugar maple Acer saccharum and its constituent acertannin. Food Chem 2010, 123:390-394.

110. Honma A, Koyama T, Yazawa K: Anti-hyperglycaemic effects of the Japanese red maple Acer pycnanthum and its constituents the ginnalins B and C. Journal of Enzyme Inh and Med Chem 2011, 26:176-180.

111. Nampoothiri SV, Prathapan A, Cherian OL, Venugopalan V, Sundaresan A: In vitro antioxidant and inhibitory potential of Terminalia bellerica and Emblica officinalis fruits against LDL oxidation and key enzymes linked to type 2 diabetes. Food and Chem Toxic 2010, 49:125-131.

112. Zhang L, Bai B, Liu X, Wang Y, Li M, Zhao D: $\alpha$-Glucosidase inhibitors from Chinese Yam (Dioscorea opposita Thunb.). Food chem 2011, 126:203-206.

113. Shirosaki M, Koyama T, Yazawa K: Anti-hyperglycemic activity of kiwifruit leaf (Actinidia deliciosa) in mice. Biosci Biote and Bioch 2008, 72:1099-1102. 